\title{
Dysregulation of Superoxide Dismutase in Chronic Kidney Disease
}

See Akiyama et al., Nephron Clin Pract 2005;99:c107-c114

\author{
M. Kelly ${ }^{a}$ B. Lacour ${ }^{a} \quad$ T. Nguyen-Khoa ${ }^{a, b}$ \\ a Laboratory of Biochemistry A, and ${ }^{\mathrm{b}}$ INSERM U507, Necker Hospital, Paris, France
}

Chronic kidney disease (CKD) is commonly reported to be associated with oxidative stress but there is still controversy on the mechanism. Numerous sources of radical oxygen species (ROS) have been identified in CKD patients, especially in hemodialysis (HD) patients. Macrophage activation, which produces ROS, is due in these patients to: accumulation of uremic toxins; dialysis membrane bio-incompatibility; influx of endotoxins from the dialysate, and immunologic and metabolic disorders such as diabetes and dyslipidemia [1]. Phagocyte myeloperoxidase-mediated events have also been associated with the production of oxidized low-density lipoprotein [2]; advanced oxidation protein products and advanced glycation end products, which are considered potent mediators of inflammation [3]. Moreover, treatment of anemia with high levels of iron may induce oxidative stress [4]. The massive generation of ROS is all the more damaging given that CKD patients have a weaker antioxidant system due to a diet low in antioxidant vitamins and oligoelements [5] and due to loss of antioxidants during HD sessions [6].

The superoxide dismutase (SOD) is the front line of defence against superoxide anions $\left(\mathrm{O}_{2}^{\overline{2}}\right)$ and detoxifies $\mathrm{O}_{2}^{-}$into hydrogen peroxide $\left(\mathrm{H}_{2} \mathrm{O}_{2}\right)$. SOD is a metalloenzyme existing in three different isoforms [7]: the cytoplasmic copper-zinc SOD (Cu/Zn-SOD); the mitochondrial manganese SOD (Mn-SOD) and the extracellular SOD found in interstitial fluid, plasma, lymph and synovial fluid.

Few studies have looked at SOD activity and its expression in CKD patients; the present study by Akiyama et al. [8] published in this issue of Nephron Clinical Practice is one of them. The authors found a significant increase in SOD activity in leucocytes in CKD patients, but this increase affects only $\mathrm{Cu} / \mathrm{Zn}$-SOD. Moreover, $\mathrm{Cu} / \mathrm{Zn}$ SOD mRNA expression in leucocytes was also significantly higher as compared to controls. This latter result is in line with an earlier study [9], in which an increase in SOD expression in white blood cells in CKD patients was also found. However, this increase in SOD activity is in contrast to the results of several studies, in which a decrease in erythrocyte SOD activity in CKD patients was observed [5, 10, 11]. Furthermore, we must be careful when comparing these different studies, since different sources of cells were used. Knowing that erythrocytes in CKD patients could have a shorter life span because of anemia, it is possible that this shorter life span could explain the difference in SOD levels between these studies. This discrepancy raises the question as to the ideal blood element in which to evaluate SOD activity in CKD patients.

The role of SOD and its different isoforms in the antioxidant defence mechanism in CKD patients is currently unclear. In light of the importance of myeloperoxydase

\section{KARGER \\ Fax +4161306 1234 E-Mail karger@karger.ch} www.karger.com

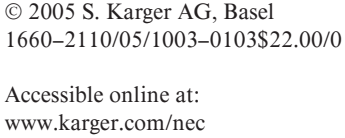

T. Nguyen-Khoa

Biochemistry A

149 , rue de Sèvres

FR-75743 Paris Cedex 15 (France)

Tel. +3314449 5485, Fax +3314449 5120, E-Mail nguyen-khoa@necker.fr 
and chlorinated stress in CKD patients [3, 11, 12], as well as in the general population [13], it seems of capital importance to evaluate simultaneously SOD activity and chlorinated stress markers to determine to what extent chlorination occurs in consequence to SOD dysregulation. Whether or not the induction of $\mathrm{Cu} / \mathrm{Zn}-\mathrm{SOD}$ expres- sion and activity in leucocytes is sufficient to protect CKD patients against oxidative stress cannot be determined in the study by Akiyama et al. [8], since the authors did not measure chlorinated stress markers. Therefore, the place of SOD activation as a therapeutic strategy remains elusive.

\section{References}

1 Locatelli F, Canaud B, Eckardt KU, Stenvinkel $\mathrm{P}$, Wanner C, Zoccali C: Oxidative stress in end-stage renal disease: An emerging threat to patient outcome. Nephrol Dial Transplant 2003; 18:1272-1280.

2 Nguyen-Khoa T, Massy ZA, Witko-Sarsat V, Canteloup S, Kebede M, Lacour B, Drüeke T, Descamps-Latscha B: Oxidized low-density lipoprotein induces macrophage respiratory burst via its protein moiety: A novel pathway in atherogenesis? Biochem Biophys Res Commun 1999;263:804-809.

3 Witko-Sarsat V, Friedlander M, Nguyen-Khoa T, Capeillere-Blandin C, Nguyen AT, Canteloup S, Dayer JM, Jungers P, Drüeke T, Descamps-Latscha B: Advanced oxidation protein products as novel mediators of inflammation and monocyte activation in chronic renal failure. J Immunol 1998;161:2524-2532.

4 Drüeke T, Witko-Sarsat V, Massy Z, Descamps-Latscha B, Guerin AP, Marchais SJ, Gausson V, London GM: Iron therapy, advanced oxidation protein products, and carotid artery intima-media thickness in end-stage renal disease. Circulation 2002;106:22122217.
5 Bonnefont-Rousselot D, Lehmann E, Jaudon MC, Delattre J, Perrone B, Rechke JP: Blood oxidative stress and lipoprotein oxidizability in haemodialysis patients: Effect of the use of a vitamin E-coated dialysis membrane. Nephrol Dial Transplant 2000;15:2020-2028.

6 Nguyen-Khoa T, Massy ZA, Witko-Sarsat V, Thevenin M, Touam M, Lambrey G, Lacour B, Drüeke TB, Descamps-Latscha B: Critical evaluation of plasma and LDL oxidant-trapping potential in hemodialysis patients. Kidney Int 1999;56:747-753.

7 Fridovich I: Superoxide radical and superoxide dismutases. Annu Rev Biochem 1995:64: 97-112.

8 Akiyama $\mathrm{S}$, Inagaki $\mathrm{M}$, Tsuji $\mathrm{M}$, Gotoh $\mathrm{H}$, Gotoh T, Gotoh Y, Oguchi K: mRNA Study on $\mathrm{Cu} / \mathrm{Zn}$ Superoxide Dismutase Induction by Hemodialysis Treatment. Nephron Clin Pract 2005;99:107-114.

9 Schettler V, Kuhn W, Kleinoeder T, Armstrong VW, Oellerich M, Muller GA, Wieland E: No acute impact of haemodialysis treatment on free radical scavenging enzyme gene expression in white blood cells. J Intern Med 2003; 253:201-207.
10 Ceballos-Picot I, Witko-Sarsat V, MeradBoudia M, Nguyen AT, Thevenin M, Jaudon MC, Zingraff J, Verger C, Jungers P, Descamps-Latscha B: Glutathione antioxidant system as a marker of oxidative stress in chronic renal failure. Free Radic Biol Med 1996;21: 845-853.

11 Nguyen-Khoa T, Massy ZA, De Bandt JP, Kebede M, Salama L, Lambrey G, Witko-Sarsat V, Drüeke TB, Lacour B, Thevenin M: Oxidative stress and haemodialysis: Role of inflammation and duration of dialysis treatment. Nephrol Dial Transplant 2001;16:335-340.

12 Himmelfarb J, McMenamin ME, Loseto G, Heinecke JW: Myeloperoxidase-catalyzed 3chlorotyrosine formation in dialysis patients. Free Radic Biol Med 2001;31:1163-1169.

13 Zheng L, Nukuna B, Brennan ML, Sun M, Goormastic M, Settle M, Schmitt D, Fu X, Thomson L, Fox PL, Ischiropoulos H, Smith JD, Kinter M, Hazen SL: Apolipoprotein A-I is a selective target for myeloperoxidase-catalyzed oxidation and functional impairment in subjects with cardiovascular disease. J Clin Invest 2004;114:529-541. 